\title{
Knowledge of, risk perception towards and reported preventive practices against Lassa fever among health workers in Ondo State, Nigeria
}

\author{
Akinola Ayoola Fatiregun ${ }^{1 *}$, Elvis E Isere ${ }^{1}$, Opeyemi Agunbiade ${ }^{2}$, Modupeola Dosumu ${ }^{1}$, Rosemary \\ Onyibe $^{3}$
}

\begin{abstract}
Background: Secondary transmission of Lassa fever has been recorded annually among healthcare workers who provided care. An outbreak of the disease in Ondo State, Southwest Nigeria in 2018, recorded high morbidity and mortality. This study was conducted to assess the knowledge, risk perception, and preventive practices towards Lassa fever among healthcare workers.
\end{abstract}

Methods: A health facility-based descriptive cross-sectional study design was conducted involving senior members of staff randomly selected from the list of staff members. A structured pre-tested questionnaire was administered to 554 consenting respondents in 304 health facilities.

Results: More than half of the respondents $(317,57.2 \%)$ are health workers in primary healthcare cadres. Although $444(80.1 \%)$ knew the case definition for reporting, only $379(68.4 \%)$ correctly indicated the reporting channel. Concerning risk perception, $174(31.4 \%)$ rated their risk of contracting the disease in the workplace as high, and $309(55.8 \%)$ indicated that hospitals' infection control policy is inadequate. Furthermore, only $76(13.7 \%)$ of the respondents reported having modified their working habits for fear of being infected with Lassa fever three months before the study with $368(66.4 \%)$ and $474(85.6 \%)$ reported that they always use aprons and gloves respectively during treatment of patients.

Conclusion: There is a need to strengthen the hospital infection control policy and train healthcare workers on reporting suspected cases.

Keywords: Lassa fever outbreak; Risk perception; Infection prevention practices; Healthcare workers, Nigeria

\section{Background}

Lassa fever, a highly infectious hemorrhagic illness, is caused by a virus in the Arenaviridae family [1,2]. Its animal host is a multimammate rat, Mastomys natalensis, which is present in most parts of Nigeria [2]. The disease usually presents fever, muscle aches, sore throat, nausea, vomiting, chest and abdominal pain, and hemorrhage from the body's orifices [3]. The mode of transmission is through contact with the excreta or urine of the rodent in food or during the hunting and processing of rats for consumption or by consuming food items contaminated with the virus from the excreta/urine of these rats. The virus is transmitted from person to person, either within households during care for sick relatives or in health care settings [4]. Exposure to blood and other infected body fluids through the skin or mucous membranes, especially if the fluids

*Correspondence: fatireguna@who.int

${ }^{1}$ World Health Organization Ondo State Office, Akure, Nigeria

Full list of author information is available at the end of the article contain blood, results in the secondary human spread. This type of transmission is the most likely route in healthcare settings [5]. The disease is endemic in the country, and parts of West Africa and outbreaks have been reported annually [6]. Lassa fever presents at its early stages with syndromes not easily distinguishable from other viral, bacterial, or parasitic infections common in the tropics such as malaria, typhoid, and other hemorrhagic fevers, hence causing early diagnosis to be difficult $[7,8]$. Late diagnosis and treatment have been reported to increase secondary transmission likelihood, including nosocomial transmission [9]. Other factors contributing to nosocomial Lassa infection include poor knowledge of the disease and infection control techniques, low-risk perception about the infectiousness of the disease, poor compliance to universal precautionary measures, structural challenges like lack of isolation wards in hospitals, inadequate provision of personal protective equipment (PPE) and lack of screening and confirmatory tests among others [8-12]. 
An outbreak of Lassa fever was confirmed in Nigeria in January 2018, with several states affected, including Ondo State. Surveillance data earlier in 2018 shows that fourteen health care workers providing care for Lassa fever patients in various hospitals in six states (Benue, Ebonyi, Edo, Kogi, Nasarawa, and Ondo) of Nigeria were affected with four deaths recorded (case fatality rate of 29\%) [13]. Hence, we assessed the knowledge, risk perception, and preventive practices towards Lassa fever among healthcare providers in Lassa fever affected Local Government Areas (LGAs) of Ondo State, Southwest, Nigeria.

\section{Methods}

Study setting

This study was conducted in Ondo State, Nigeria. The State is one of the 36 states in the Federal Republic of Nigeria situated between longitudes $40151 \mathrm{E}$ and $60001 \mathrm{E}$ of the Greenwich meridian and latitudes $50451 \mathrm{~N}$ and $70451 \mathrm{~N}$, which are to the North of the equator, in the Southwestern geopolitical zone of the country. The states bordering Ondo State are Ekiti State to the North, Kogi State to the northeast, Edo State to the East, Delta State to the southeast, Ogun State to the southwest, and Osun State to the northwest. The state is divided into three senatorial districts (Ondo-North, Ondo-Central, and OndoSouth) with 18 LGAs and a 2018 projected total population of $4,906,078$ based on the 2006 population census [7]. The outbreak was restricted to six LGAs (Akure North, Akure South, Akoko South West, Ose, Owo, and Idanre) in the north and central senatorial districts. There are 101 private and 225 government-owned health facilities in the six local government areas.

\section{Study design}

A descriptive cross-sectional health facility-based study design was carried out in May 2018. The study population was healthcare workers in all government-owned and private hospitals in the six LGAs affected by the Lassa fever outbreak in 2018 in the State. The healthcare workers are clinical staff members, namely, medical doctors, nurses, midwives, Community Health Officers, Community Health Extension Workers, pharmacists, and medical laboratory technologists. We estimated that 402 clinical workers in an affected LGA would be required to obtain a $38.9 \%$ proportion of health workers with good knowledge based on a previous study [8], with a desired absolute accuracy of 5\% at type 1 error of a twosided test, alpha of 0.05 and assuming a $10 \%$ non-response rate. All the health facilities in the LGAs were visited for the selection of participants. A simple random sampling technique was employed to select consenting participants who were clinical staff with employment in a health facility for at least three months prior to the study's date. At each health facility visited, a list of all clinical staff on duty roster was obtained, and two clinical healthcare workers were selected randomly by balloting. In a health facility where there was only one clinical staff who meets the criteria, the officer was sampled purposively.

\section{Data collection and analysis}

A structured questionnaire was administered to participants by trained research assistants using the Open Data Kit (ODK) application. The questionnaire was developed by researchers from the literature reviewed and captured information on sociodemographic variables, including sex, age, religion, occupation, ethnicity, marital status, educational level, and LGA. Others were variables assessing knowledge, risk perception, and practice of reporting regarding Lassa fever. The draft questionnaire was reviewed, and face validated by colleagues at the State Ministry of Health. It was also pilot tested before the final version was administered. The data obtained were analyzed using IBM SPSS version 20.0 statistical software. A reported preventive practice score was obtained by scoring each of 39 -item variables with " 1 " assigned for reported adherence to correct practice and " 0 " assigned for non-adherence. A total reported practice score of 39 with a range of $0-19$ scores $(0-49 \%)$ was considered poor reported practice, while scores 20-39 (50-100\%) were deemed to be good. Bivariate and multivariate logistic analyses were conducted with respondents' sociodemographic characteristics as independent variables and reported practices against Lassa fever categorized as good and poor as the dependent variable. Variables in the bivariate analysis with a p-value of $<0.2$ were included in the multivariate model, and a p-value $<0.05$ was accepted as statistically significant.

\section{Results}

Sociodemographic characteristics of participants

Table 1 shows the demographic characteristics of the respondents. The mean age was $37.9 \pm 11.0$ years, and the majority $[463 ; 83.6 \%]$ were females. Moreover, $221(72.7 \%)$ of the respondents were from public health facilities. Very few 3 $(0.5 \%)$ were midwives in training, $13(2.3 \%)$ were nurses in training, $24(4.3 \%)$ were laboratory assistants, $47(8.5 \%)$ were medical officers, 64(11.6\% ) were nursing assistants, $26(4.7 \%)$ were midwives, $60(10.8 \%)$ were nurses, while $317(57.2 \%)$ were others including Community Health Extension Workers (the CHEWS and the JCHEWS) and Medical Record Officers. The majority of the respondents, 402 (72.6\%) were married, and $483(87.2 \%)$ had a tertiary education certificate. About half 244 $(44.1 \%)$ had their years of practice below six years.

\section{Respondents knowledge of Lassa fever}

Table 2 shows the respondents' knowledge of Lassa fever. A few $17(3.1 \%)$ indicated that Lassa fever is a bacterial disease, a wrong knowledge of the cause of the disease. However, almost all $535(96.6 \%)$ indicated correct knowledge of incubation period; 3 to 21 days and $533(96.2 \%)$ indicated correctly that the reservoir is a rat. Besides, 551 (99.5\%) agreed that Lassa fever could be transmitted from person to person through direct contact with infected body fluid. Regarding the knowledge of symptoms of the disease, $484(87.4 \%)$ correctly indicated that fever is a symptom of Lassa fever; however, 103 (18.6\%) wrongly claimed that tremor is a symptom of the disease. On the knowledge of the reporting of the disease, 110 (19.9\%) of the respondent could not correctly affirm the case definition for reporting, although 536 (96.8\%) confirmed that it is most appropriate to report immediately a suspected case of Lassa fever seen. Only $379(68.4 \%)$ of the respondents correctly indicated that the Local government disease surveillance officer was the person to report a suspected case. 
Table 1 Sociodemographic characteristics of the respondents $(\mathrm{n}=554)$

\begin{tabular}{|c|c|c|}
\hline Variables & $\mathbf{N}$ & $\%$ \\
\hline \multicolumn{3}{|l|}{ Sex } \\
\hline Female & 463 & 83.6 \\
\hline Male & 91 & 16.4 \\
\hline \multicolumn{3}{|l|}{ Age group (years) } \\
\hline$<30$ & 152 & 27.4 \\
\hline $30-39$ & 169 & 30.5 \\
\hline$\geq 40$ & 233 & 42.1 \\
\hline \multicolumn{3}{|l|}{ Type of health facility } \\
\hline Private & 83 & 27.3 \\
\hline Public & 221 & 72.7 \\
\hline \multicolumn{3}{|l|}{ Qualification } \\
\hline Enrolled midwife & 3 & 0.5 \\
\hline Enrolled nurse & 13 & 2.3 \\
\hline Laboratory assistant & 24 & 4.3 \\
\hline Medical officer & 47 & 8.5 \\
\hline Nursing assistant & 64 & 11.6 \\
\hline Registered midwife & 26 & 4.7 \\
\hline Registered nurse & 60 & 10.8 \\
\hline Primary healthcare cadre & 317 & 57.2 \\
\hline \multicolumn{3}{|l|}{ Marital status } \\
\hline Married & 402 & 72.6 \\
\hline Single & 146 & 26.4 \\
\hline Widowed & 6 & 1.1 \\
\hline \multicolumn{3}{|l|}{ Educational level } \\
\hline Primary & 4 & 0.7 \\
\hline Secondary & 67 & 12.1 \\
\hline Tertiary & 483 & 87.2 \\
\hline \multicolumn{3}{|l|}{ Years of practice } \\
\hline$<6$ & 244 & 44.1 \\
\hline $6-15$ & 153 & 27.7 \\
\hline$\geq 16$ & 157 & 28.2 \\
\hline
\end{tabular}

Respondents risk perception

Concerning respondents' risk perception, only 174 (31.4\%) and $148(26.7 \%)$ of the health workers rated their risks of contracting the disease in their workplace and at home as high, respectively. However, almost all 542 (97.8\%) indicated that health workers who do not observe universal precautionary measures are at high risk of Lassa fever infection. Besides, 550 $(99.3 \%)$ of the respondent concurred that touching bodies of dead Lassa fever cases can constitute a potential hazard and agreed that touching saliva, urine, and other body fluids of Lassa fever cases pose a risk for infection. Moreover, 543 (98.0\%) agreed that not washing of hands after touching patients or clinical procedure increases the risk of Lassa fever infection, (Table 3).

\section{Respondents reported preventive practices}

With regards to reported preventive practices against the disease, table 4 shows that only $76(13.7 \%)$ of respondents had modified their working habits because of fear of getting Lassa fever in the last three months before the survey. About 368 $(66.4 \%)$ of the respondents reported always use of apron, while $474(85.6 \%)$ reported always use of gloves, and 157 (28.3\%) reported always use of boots as a preventive measure to avoid the spread of the disease. Majority 524 (94.6\%) reported always washing their hands, and $447(80.7 \%)$ wash their hands with soap and water, while $57(9.8 \%)$ wash their hands with disinfectant and $50(9.5 \%)$ wash their hands with water only. The association between reported practices and location, health facility type, gender, age, marital status, qualification, educational level years of practice, and overall knowledge shows none of the variables statistically significant.

Table 2 Knowledge of respondents on Lassa fever $(\mathrm{n}=554)$

\begin{tabular}{|c|c|c|}
\hline Variables & $\mathbf{N}$ & $\%$ \\
\hline \multicolumn{3}{|l|}{ Knowledge of cause and transmission } \\
\hline Lassa fever is a bacterial disease & 17 & 3.1 \\
\hline Lassa fever is a viral disease & 518 & 93.5 \\
\hline The incubation period lasts from 3 to 21 days & 535 & 96.6 \\
\hline The reservoir is a rat & 533 & 96.2 \\
\hline $\begin{array}{l}\text { Lassa fever can be transmitted from person to person } \\
\text { through direct contact with infected body fluid. }\end{array}$ & 551 & 99.5 \\
\hline Lassa fever can be transmitted from animal to person & 553 & 99.8 \\
\hline $\begin{array}{l}\text { Lassa fever can be transmitted from inanimate objects } \\
\text { (fomites) to person? }\end{array}$ & 446 & 80.5 \\
\hline
\end{tabular}

\section{Knowledge of symptoms}

Fever $>38^{\circ} \mathrm{C} \quad 484 \quad 87.4$

$\begin{array}{lrr}\text { Tremor } & 103 & 18.6\end{array}$

$\begin{array}{lll}\text { Photophobia } & 473 & 85.4\end{array}$

$\begin{array}{lll}\text { Paralysis } & 473 & 85.4\end{array}$

$\begin{array}{lll}\text { Sore throat } & 325 & 58.7\end{array}$

$\begin{array}{lll}\text { Unexplained bleeding mucosal bleeding } & 392 \quad 70.8\end{array}$

$\begin{array}{lll}\text { Vomiting and Diarrhea is a sign } & 471 & 85.0\end{array}$

At an early stage, patient present at the health facility $\quad \begin{array}{lll}343 & 61.9\end{array}$

like Malaria case

$\begin{array}{lll}\text { Neck stiffness } & 318 & 57.4\end{array}$

$\begin{array}{lll}\text { Blindness } & 465 & 83.9\end{array}$

\section{Knowledge of reporting}

Any person with history with a probable or confirmed $\quad 444 \quad 80.1$ Lassa fever case within 21 days of onset of symptoms is a suspected case.

It is most appropriate to report a suspected case of $\quad 536 \quad 96.8$

Lassa fever seen in the health facility immediately.

Any suspected case who died without a collection of $\quad 495 \quad 89.4$ specimens for laboratory testing is probable.

Any suspected case with laboratory confirmation is a $\quad 550 \quad 99.3$ confirmed case.

Local government area disease surveillance officer $379 \quad 68.4$ should be notified when a suspected Lassa fever case is seen in the hospital.

Notification is done through phone calls and by $467 \quad 84.3$ completing the immediate case reporting form.

\section{Discussion}

Healthcare settings will continue to play a critical role in the spread of viral hemorrhagic fevers, including Lassa fever with enormous impact in human lives and costs of management of cases, contact tracing, and containment [5]. Therefore, continuous assessment to identify gaps in knowledge and focus education of healthcare workers about safe clinical and infection control practices will go a long way in the prevention of the nosocomial spread of the diseases. We essentially found that our respondents' overall knowledge, perception, and 
practices were good, although substantial gaps still exist in some areas that need to be specifically addressed.

Most of our respondents were females. A similar study in a neighboring state in the country also reported a greater number of female to male workers [8]. This is likely to reflect the differential role of gender in the health profession. Females were more likely to be nurses, midwives, auxiliaries, community health, and extension workers. The health workers were also in their prime of life, emphasizing the need to protect them from hospital infections. These findings and assertions are supported by a previous study [14]. We have the majority of our health workers from public facilities, a finding that we believe represents the distribution of private-public facilities in the State. A study found no statistically significant difference between the knowledge, attitude, and practice of healthcare workers regarding Ebola Viral Disease, a similar Viral Hemorrhagic Fever in the same group with Lassa fever among public and private healthcare workers in Lagos, Nigeria [15]. However, evidence suggests that poorly controlled medical practices, with a proliferation of small hospitals and clinics, often run with an emphasis on profit promoting the nosocomial transmission of Lassa fever [12].

On aggregate, the overall knowledge of healthcare workers was good. The knowledge of the cause, clinical presentation, transmission, standard precaution, and reporting by healthcare workers found in this study is higher than in other studies $[8,14,16]$. The higher level of knowledge in our study could be attributed to the study's timing, which was during the tail end of a Lassa fever outbreak, and possibly the effectiveness of the then ongoing sensitization activities among health workers and community members. Even though the high level of knowledge observed that critical gaps still exist. For instance, some health workers wrongly classified Lassa fever as a bacterial disease, and some reported that non-observation of universal precaution is not a risk factor. The depth and accuracy of health workers' knowledge should be such that they can effectively disseminate accurate information to peers and clients, hence the need for continuous education. In addition, the finding that about $20 \%$ could not define a suspected case correctly has negative implications in disease reporting and early diagnosis [17].

Concerning risk perception, only a third and a fifth of the health workers rated their risks of contracting the disease in their place of work and at home as high, respectively. This finding is similar to that reported among healthcare workers in a tertiary institution in the country regarding Ebola viral disease, where most respondents were reported to have had poor risk perception and negative attitude [18]. Another study inferred that porters often times have a greater perception of risks because their work often necessitates handling waste [14]. We speculate that positive illusions tend to overestimate one's control over events or the tendency to consider that bad events are more likely to happen to others than to oneself may have influenced our finding. However, studies have shown strong evidence in psychological research that these positive illusions can reduce perceptions of vulnerability to health threats and reduce preventive behavior [19].

Moreover, the finding that one-fourth of our respondents disagree that barrier nursing protects from infection signifies that a significant number of respondents have a negative attitude towards the disease preventive practices. Hence, more infection prevention and control communication engagement will be needed, focusing on those with such an attitude [20]. In addition, the finding that more than half of our respondents indicated that their facilities' infection control policy was inadequate to protect health workers against Lassa fever implies that hospital authorities and the government need to do more to implement policy targeting the disease. This finding is similar to that found among the tertiary hospital healthcare workers with regards to Ebola viral disease [18].

Table 3: Risk perception of Lassa fever $(n=554)$

\begin{tabular}{|c|c|c|}
\hline Statement of agreement & $\mathbf{N}$ & $\%$ \\
\hline $\begin{array}{l}\text { Health workers who do not observe universal } \\
\text { precautionary measures are at high risk of Lassa } \\
\text { fever infection }\end{array}$ & 542 & 97.8 \\
\hline $\begin{array}{l}\text { Touching bodies of dead Lassa fever cases can } \\
\text { constitute a potential hazard }\end{array}$ & 550 & 99.3 \\
\hline $\begin{array}{l}\text { Touching saliva, urine and other body fluids of } \\
\text { Lassa fever cases poses a risk for infection }\end{array}$ & 550 & 99.3 \\
\hline $\begin{array}{l}\text { Not washing your hands after touching patients or } \\
\text { clinical procedure increases the risk of Lassa fever } \\
\text { infection }\end{array}$ & 543 & 98.0 \\
\hline $\begin{array}{l}\text { Recapping used needles and syringes exposes health } \\
\text { workers to Lassa fever disease }\end{array}$ & 510 & 92.1 \\
\hline There is no risk in living with Lassa fever patient & 77 & 13.9 \\
\hline $\begin{array}{l}\text { The infection control policy of the hospital is } \\
\text { inadequate. }\end{array}$ & 309 & 55.8 \\
\hline Barrier nursing protects from infection & 422 & 76.2 \\
\hline $\begin{array}{l}\text { High rating of the level of risk of contracting Lassa } \\
\text { fever at home or outside your place of work }\end{array}$ & 148 & 26.7 \\
\hline $\begin{array}{l}\text { High rating of the level of risk of contracting Lassa } \\
\text { fever in place of work }\end{array}$ & 174 & 31.4 \\
\hline
\end{tabular}

Table 4 Assessment of preventive practices against Lassa fever $(\mathrm{N}=554)$

\begin{tabular}{lll}
\hline Variables & $\mathbf{N}$ & $\mathbf{( \% )}$ \\
\hline $\begin{array}{l}\text { Have you modified your working habit } \\
\text { because of fear of getting Lassa fever in the }\end{array}$ & 76 & 13.7 \\
$\begin{array}{l}\text { last three months } \\
\text { Always use an apron to avoid the spread of }\end{array}$ & 368 & 66.4 \\
$\begin{array}{l}\text { Lassa fever } \\
\text { Always use gloves to avoid contacting Lassa }\end{array}$ & 474 & 85.6 \\
$\begin{array}{l}\text { fever } \\
\text { Always use face masks to avoid contracting }\end{array}$ & 208 & \\
the disease & & \\
Always wear boots to as preventive practice & 157 & 28.5 \\
$\begin{array}{l}\text { Always washing hands } \\
\text { Hands washing with: }\end{array}$ & 524 & 94.6 \\
$\begin{array}{l}\text { With water only* } \\
\text { With water and soap* }\end{array}$ & 50 & 9.5 \\
$\begin{array}{l}\text { With disinfectant* } \\
\text { Always wash and disinfect surfaces and } \\
\text { utensils? }\end{array}$ & 492 & 80.7 \\
\hline
\end{tabular}

Only very few of our respondents had modified their working habits since the current outbreak was reported. We suspect that the low-risk perception resulting from the illusion of control previously described might be responsible [19]. Although 
almost all the healthcare workers indicated regular hand washing practices with soap and water, not all of them reported always use barrier equipment for personal protection. Previous reports have shown varied compliance levels to standard precautions among health workers, with some low reporting practices and others contrary [14]. Concerning hand hygiene, a study reported that hand washing is done while pieces of jewelry were on and, in certain cases, not done before gloves were worn poor practices, although these were not assessed in the present study [21]. The non-use of protective equipment especially boot among some of the health workers in our sample may be due to the non-availability of the equipment in their health facility, hence the need for the hospital authorities to ensure that these materials are in stock and health workers trained on their importance and use [20].

\section{Conclusion}

Finally, we recognized the limitations of the timing and design of the study imposed on our findings. Our study was conducted towards the tail end of an outbreak. Several sensitizations and engagement of the health workers on Lassa fever had been conducted, though no baseline assessment was done, however, the high levels of knowledge, positive attitude, and reported these could have influenced compliance to standard precautions we found. Moreover, none of the variables examined for association with reported practice was found to be statistically significant. However, previous studies have shown that compliance with standard precautions is associated with occupational groups within the healthcare sector and knowledge level among healthcare workers [14]. Social desirability and recall biases are known to be shortcomings of interview-based cross-sectional surveys [16]. As it has been suggested, the containment of Lassa fever transmission like any other viral hemorrhagic fever will include prompt recognition of a case upon presentation followed by immediate implementation of infection control measures and contact tracing $[5,20]$. This suggests the need to address the areas of gaps in knowledge, risk perception, and practice found among healthcare workers in endemic areas in this study. These data could be used to plan and implement focused health education and risk communication interventions to address the gaps observed.

\section{Abbreviations}

LGAs: Local Government Areas; ODK: Open Data Kit; IBM SPSS International Business Machine Cooperation Statistical Package for the Social Sciences; SMoH: State Ministry of Health; CHEWS: Community Health Extension Workers; JCHEWS: Junior Community Health Extension Workers

\section{Declarations}

\section{Acknowledgment}

We appreciate all the data collectors who ensured quality assurance during the filed data collection process and the respondents for their valuable time and data provided. The Staff of the Ondo State Primary Health Care Board, who participated in the planning and review of the data collection tool, are also acknowledged for their valuable time and contributions

\section{Funding}

Financial support was received from the World Health Organization for the outbreak investigation
Availability of data and materials

Data will be available by emailing fatireguna@who.int

\section{Authors' contributions}

AAF conceived and designed the study, EI and OA collected and organized data. AAF, RO, and MD analyzed and interpreted data. AAF, EI, and MD wrote the initial drafts of the article, and all authors critically reviewed and approved the final draft.

\section{Ethics approval and consent to participate}

We conducted the research following the Declaration of Helsinki. The study was conducted as part of an outbreak control investigation; hence permission to conduct the study was obtained from the State Ministry of Health $(\mathrm{SMoH})$ and the LGA Primary Health Care Department. Informed consent was also obtained from the respondents. They were made to understand that participation is voluntary, and there was no consequence for non-participation. The study also enabled investigators to make recommendations to prevent further spread of Lassa fever, especially among healthcare workers, thus benefiting the study participants and their communities at large. All information obtained was kept confidential.

\section{Consent for publication}

Not applicable

\section{Competing interest}

The author declares that he has no competing interests.

\section{Open Access}

This article is distributed under the terms of the Creative Commons $\begin{array}{llll}\text { Attribution } & 4.0 & \text { International } & \text { License }\end{array}$ (http://creativecommons.org/licenses/by/4.0/), which permits unrestricted use, distribution, and reproduction in any medium, provided you give appropriate credit to the original author(s) and the source, provide a link to the Creative Commons license, and indicate if changes were made. The Creative Commons Public Domain Dedication waiver (http://creativecommons.org/publicdomain/zero/1.0/) applies to the data made available in this article, unless otherwise stated.

\section{Author details}

${ }^{1}$ World Health Organization Ondo State Office, Akure, Nigeria.

${ }^{2}$ Ondo State Primary Health Care Board, Akure, Ondo State, Nigeria.

${ }^{3}$ World Health Organization Southwest Zonal Office Ibadan, Nigeria

Article Info

Received: 24 July 2020

Accepted: 13 August 2020

Published: 18 August 2020

\section{References}

1. Bowen MD, Rollin PE, Ksiazek TG, Hustad HL, Bausch DG, Demby AH, et al. Genetic Diversity among Lassa Virus Strains. J Virol 2000; 74:6992-7004.

https://doi.org/10.1128/jvi.74.15.6992-7004.2000.

2. Ekuma AE, Akpan IS. Lassa fever and Infection Control: Knowledge, Attitudes and Practice in a University Teaching Hospital in Uyo, Nigeria. Ibom Med J 2017; 10:40-7.

3. Richmond JK, Baglole DJ. Lassa fever: epidemiology, clinica features, and social consequences. BMJ 2003; 327:1271-5. https://doi.org/10.1136/bmj.327.7426.1271.

4. Fisher-Hoch SP. Lessons from nosocomial viral haemorrhagic fever outbreaks. $\mathrm{Br}$ Med Bull 2005;73-74:123-37. https://doi.org/10.1093/bmb/ldh054. 
5. Ftika L, Maltezou HC. Viral haemorrhagic fevers in healthcare settings. J Hosp Infect 2013; 83:185-92. https://doi.org/10.1016/j.jhin.2012.10.013.

6. Isere EE, Fatiregun A, Ilesanmi O, Ijarotimi I, Egube B, Adejugbagbe A, et al. Lessons Learnt from Epidemiological Investigation of Lassa Fever Outbreak in a Southwest State of Nigeria December 2015 to April 2016. PLoS Curr 2018:1-23. https://doi.org/10.1371/currents.outbreaks.bc4396a6650d0ed1985 d731583bf5ded.

7. Fatiregun A, Isere E, Dosumu M, Agunbiade O, Onyibe R. Lassa fever awareness and knowledge among community residents in Ondo State, Nigeria. J Community Med Prim Heal Care 2019; 31:26-35.

8. Tobin E, Asogun D, Isah E, Ugege O, Ebhodaghe P. Assessment of knowledge and attitude towards Lassa fever among Primary care providers in an endemic suburban community of Edo state: implications for control. J Med Med Sci 2013; 4:311-8. https://doi.org/10.14303/jmms.2013.095.

9. Aigbiremolen A, Duru C, Awunor N, Abejegah C, Abah S, Asogun A, et al. Knowledge and application of infectious diseases control measures among Primary Care workers in Nigeria: The Lassa fever example. Int J Basic, Appl Innov Res 2012;1:122-9.

10. Lakhani A, Mahmood H, Laeeq A, Mansoor S, Lodhi S, Majid S, et al. Viral hemorrhagic fever in Pakistan: Awareness among health care personnel. J Pak Med Assoc 2002; 52:214-7.

11. Sheikh NS, Sheikh AS, Sheikh AA. Knowledge, attitude and practices regarding Crimean-Congo haemorrhagic fever among healthcare workers in Balochistan. J Ayub Med Coll Abbottabad 2004; 16:39-42.

12. Fisher-Hoch S, Tomori O, Nasidi A, Perez-Oronoz G, Fakile Y, Hutwagner L, et al. Review of cases of nosocomial Lassa fever in Nigeria: the high price of poor medical practice 1995;311:1993WHO | Lassa Fever - Nigeria. WHO 2018
13. Ekaete Alice T, Akhere AD, Ikponwonsa O, Grace E. Knowledge and practice of infection control among health workers in a tertiary hospital in Edo state, Nigeria. Direct Res J Heal Pharmacol 2013; 1:20-7.

14. Idris BJ, Inem V, Balogun M. Comparing the knowledge, attitude and practices of health care workers in public and private primary care facilities in Lagos State on Ebola virus disease. Pan Afr Med J 2015; 22:19. https://doi.org/10.11694/pamj.supp.2015.22.1.6655.

15. Olowookere SA, Fatiregun AA, Gbolahan OO, Adepoju EG. Diagnostic proficiency and reporting of Lassa fever by physicians in Osun State of Nigeria. BMC Infect Dis 2014; 14:344. https://doi.org/10.1186/1471-2334-14-344.

16. Odega CC, Fatiregun AA, Osagbemi GK. Completeness of suspected measles reporting in a southern district of Nigeria. Public Health 2010;124. https://doi.org/10.1016/j.puhe.2009.11.004.

17. Olowookere SA, Abioye-Kuteyi EA, Adepoju OK, Esan OT, Adeolu TM, Adeoye TK, et al. Knowledge, Attitude, and Practice of Health Workers in a Tertiary Hospital in Ile-Ife, Nigeria, towards Ebola Viral Disease. J Trop Med 2015; 2015:431317. https://doi.org/10.1155/2015/431317.

18. Sridhar S, Brouqui P, Fontaine J, Perivier I, Ruscassier P, Gautret $\mathrm{P}$, et al. Risk perceptions of MSF healthcare workers on the recent Ebola epidemic in West Africa. New Microbes New Infect 2016; 12:61-8. https://doi.org/10.1016/j.nmni.2016.04.010.

19. Fatiregun AA, Isere EE. Epidemic preparedness and management: A guide on Lassa fever outbreak preparedness plan. Niger Med J 2017; 58:1-6. https://doi.org/10.4103/0300-1652.218414.

20. Jumaa PA. Hand hygiene: Simple and complex. Int J Infect Dis 2005;9:3-14. https://doi.org/10.1016/j.ijid.2004.05.005. 